Journal of Information Systems Engineering

\& Management, 2018, 3(1), 04

ISSN: 2468-4376

\title{
Facebook Satisfaction and Its Impacts on Fundraising: A Case Study at a Portuguese Non-Profit Organization
}

\author{
Raul M. S. Laureano ${ }^{1}$, Adriana L. Fernandes ${ }^{1}$, Sara Hassamo ${ }^{1}$, Bráulio Alturas ${ }^{1 *}$ \\ ${ }^{1}$ Instituto Universitário de Lisboa (ISCTE-IUL), Lisboa, PORTUGAL
}

*Corresponding Author: braulio.alturas@iscte-iul.pt

Citation: Laureano, R. M. S., Fernandes, A. L., Hassamo, S. and Alturas, B. (2018). Facebook Satisfaction and Its Impacts on Fundraising: A Case Study at a Portuguese Non-Profit Organization. Journal of Information Systems Engineering \& Management, 3(1), 04. https://doi.org/10.20897/jisem.201804

Published: January 23, 2018

\begin{abstract}
Non-profit organizations have invested in the development of content for their Facebook pages, believing be an efficient and effective means to publicize its mission and raising resources, whether monetary or human. The purpose of this study is to assess the satisfaction of the participants with the Facebook page, and how that satisfaction influences the dissemination of the organization through the word-of-mouth and the donations practices. In this context, a questionnaire was administered to 204 participants that were aware of the Portuguese non-profit organization "Leigos para o Desenvolvimento" (People for Development). The results show that the participants are satisfied with Facebook page of the organization, and that there is influence of satisfaction on the word-of-mouth and on the frequency and amount of donations. However, satisfaction with the Facebook, itself, does not appear crucial to the realization of donations, either in the present or in future as intended. The study focuses only on one organization and includes a sample that may not represent all the population extracts and so inhibit the generalization of the findings to other populations. The paper includes implications for the development of an effective use of the Facebook as a digital marketing tool that can contribute to the sustainability of non-profit organizations. The study confirms the importance of the Facebook as a digital marketing tool that can contribute to the sustainability of non-profit organizations.
\end{abstract}

Keywords: NGO, Facebook, word-of-mouth, donations, fundraising, Leigos para o Desenvolvimento, non-profit organizations

\section{INTRODUCTION}

Non-governmental organizations (NGO) are of great importance worldwide. In Portugal, the Social Economy, of which the NGO are part, represented $5.2 \%$ of total employment and $2.8 \%$ of the Gross National Product and Gross Value Added in 2013, a figure that is higher than that of activities such as electricity and telecommunications (CASES, 2016).

These organizations are self-sustaining, or financed by public or/and private resources, to carry out their activity. In a period of major financial instability, where public funding is increasingly low, these organizations seek other sources of funding, particularly individual donors, since they can guarantee their financial sustainability. Thus, it is essential to communicate well with potential funders and account for their activity to the various stakeholders (Andrade and Franco, 2007).

Information and Communication Technologies (ICT) can assist these organizations in these tasks. By connecting companies, information, knowledge and people (Jesus et al., 2013), facilitate communication, accountability, and provide transparency, which leads to increased public confidence and participation. In addition, 
ICT enable the dissemination of the mission, objectives and values of these organizations in an economic way. Consequently, ICT can be a determining factor in the fundraising activity for NGOs.

In the Portuguese context, Facebook is the dominant social network and most recognized by users of online social networks, presenting a notoriety of $98 \%$. Facebook is the social network where most of individuals are enrolled. It is the most valued and credible network, the one that best informs, the most liked and the one that has the most useful information (Marktest, 2014).

Currently many NGOs are present in the social media (Guo and Saxton. 2014; Cho et al., 2014; Young, 2017). The presence of NGOs in social networks, promoting good relationships with current and potential donors, contributes to establishing long-term loyalty relationships with individuals through satisfaction and trust (Pritchard et al., 1999). This relationship can encourage word-of-mouth, that is, the exchange of interpersonal information about an organization or the sharing of an experience with an organization (Higie et al., 1987; Cheung and Thadani, 2012). The word-of-mouth is a powerful marketing tool, which when done through social networks can become viral (Subramani and Rajagopalan, 2003; Cheung, et al., 2008). On the other hand, posts placed on Facebook, both by organizations and visitors to the page, can encourage donations (Waters and Lo, 2012).

It is in this scenario of the relationship between social networks and certain pro-social behaviors that the objectives of this study are defined: (i) evaluate satisfaction with an NGO's Facebook page; And (ii) assess how satisfaction with the organization's Facebook page influences word-of-mouth and donation practices, both in historical terms and in intent to donate in the future.

For this purpose, we selected "Leigos para o Desenvolvimento", a Non-Governmental Development Organization (NGDO), whose mission is to "promote the comprehensive and integrated development of people and communities in developing countries and Portugal, in order to their empowerment and autonomy, through the testimony and preferential intervention of qualified missionary volunteers" as presented on their webpage (Leigos para o Desenvolvimento, 2015).

In view of the objectives, the paper is structured in five sections, besides this introduction. Section two is a brief review of the literature on NGDOs, social networks and satisfaction with Facebook and its impacts. The third section presents the methodology used, with emphasis on the data collection instrument and data analysis techniques used. Fourth section presents the results. The article ends with the presentation of the main findings and identifying the contributions and limitations of the study.

\section{LITERATURE REVIEW}

\section{Non-Governmental Development Organizations}

NGDO is a legal person by private law and non-profit, which include organizations that increase action in developing countries in humanitarian and emergency relief, protection and promotion of human rights and development cooperation (Couttenier and Hatte, 2016). Or, more broadly, they are public service organizations, which function as independent bodies of volunteers and self-government operating based on common values or interests (Hoogesteger, 2016). In this way, these organizations are part of a larger sector, the Social Economy or the Third Sector, where the activity and sense of existence resides, essentially, in the people and in the social utility (Couttenier and Hatte, 2016). The fulfillment of the mission and the exercise of the activities of these organizations is self-sustaining, or financed by public and private resources. The resources included are human, material and financial resources.

Regarding the resources, these organizations are often dependent on the support of outside entities, like their donors or funders. The relationship between these and organizations should be based on trust, supported by transparency and accountability (Andrade and Franco, 2007). According to the study, Portugal's Nonprofit Sector in Comparative Context (Salamon et al., 2012), carried out in Portugal and presenting data for 2006, own revenues, which include private payments for goods and services, contributions and investment income, are the dominant source $(59 \%)$ of NGO resources. Funding from these organizations comes from external entities, $41 \%$ of which are Government funds and only 10\% of the funds come from philanthropy (including individual donations, foundations and entrepreneurs). In a generic analysis, it can be concluded that the activity of NGOs remains very dependent on public funding, which from the point of view of economic sustainability is worrying, since the diversification of sources of financing guarantees autonomy consistency and coherence in the accomplishment of the mission (Azevedo and Couto, 2012).

State funding to NGOs is on the decline, however the accuracy in evaluating the effectiveness of NGOs by the State, is increasing. Likewise, companies and individuals that contribute to NGOs are more demanding when choosing the organization to support (Azevedo and Couto, 2012). Thus, this sector has faced a strong competition and has been suffering from a decrease in available resources. NGOs have become market-oriented (Modi, 2012), due to the need to maintain current funding and promote new ones. 
It is therefore necessary to establish a transparency and openness relationship with funders, which can only be achieved by: (i) disseminating information on performance in the projects developed; (ii) requesting feedback; and (iii) degree of satisfaction on the part of these entities (Kaplan, 2001). This position promotes the satisfaction of the funders and the trust they place in the projects, which increases the support provided by them.

It is in this context that ICT, and particularly digital and interactive marketing tools, can play a key role. On the one hand, the attraction of resources through, among others, online collective financing platforms, known worldwide as crowdfunding platforms, that allow collective financing to overcome geographical limitations (Hollow, 2013; Wheat et al., 2013). On the other hand, in the dissemination of the mission, projects, events and other content through social networks such as Facebook, Youtube, LinkedIn, Twitter, Hi5, Bebo and MySpace, where more and more users communicate and share content (Belo et al., 2013).

\section{Social Network Sites}

The concept of social networks, related to information technologies, has its genesis in Web 2.0. This corresponds to a set of tools and websites that allow the collaboration and participation of individuals. Social networks aim to promote and support the establishment of virtual relationships between individuals, between organizations and between individuals and organizations, and can foster the creation of relationships between individuals who, in a non-digital environment, would not establish any kind of link (Martins et al., 2015).

Social networks have opened new opportunities, allowing low-cost communication and generating benefits for companies and for the general population, given the ease of communication and the speed of information diffusion (Belo et al., 2013). The various social networks, among them Facebook, have seen more and more users communicate and share content (Kane et al., 2014), and have become a recent global phenomenon in human communication and interaction (Pinho, 2013).

The study "The use of the Internet in Portugal 2010" (LINI, 2010) concludes that about 64.8\% of social network users in Portugal consider it important that companies have a profile in these networks. Online presence has attracted more attention from the scientific community in conducting research on social networks and its benefits to organizations (Belo et al., 2013).

In relation to NGOs, social networks have provided an unprecedented arsenal of resources to disseminate their messages and communicate directly with stakeholders, including donors, supporters, clients, and the media. People have begun to rely on the Internet as a source of primary information, organizations have begun to develop a dynamic web presence, fostering interactivity. Sites such as Facebook offer organizations an environment that promotes linking and dialogue, so it cannot be accessed independently through their websites (Waters and Lo, 2012).

Facebook is a good example of a social network that has been widely discussed in the literature because of its enormous potential to disseminate information, its credibility, and its geographic scope (Ellison, et al., 2007; Mazman and Usluel, 2010; Waters and Lo, 2012; Moro et al., 2016). This social network is characterized by its generalist nature, allowing infinite forms and contexts of interaction. According to Rebelo and Alturas (2011) the mentioned reasons and the ability to be a marketing tool used to create buzz makes it the ideal study subject in this context. Facebook can be a good platform for advertising, but we still need further empirical and objective observations capable of assessing the effectiveness of advertising relative to users of the online social network sites (Barreto, 2013).

\section{Satisfaction with Facebook and Its Impacts}

Facebook is the most used social network in the world, with a monthly average of 1.28 billion active users in 2014, followed by Youtube with 1 billion and Google+ with 540 million (Moro et al., 2016). The application provides a personalized profile for each user, while allowing them to communicate, share information and ideas, create photo albums, form and become part of social interest groups, and, among other things, influence people. For these reasons, Facebook is systematically accessed by millions of users, becoming part of people's everyday lives (Mazman and Usluel, 2010).

Since Facebook is the most credible network from the perspective of social network users (Marktest, 2014), it has been targeted and used by organizations, making it an environment that promotes the relationship and dialogue with its followers. The organization, by sending a message through its updating "state", becomes visible to its followers and fans, who in turn can express themselves about the update and share it with other friends and family (Waters and Lo, 2012). The exploitation of the commercial aspect of Facebook enables organizations to make disclosure of its products and services and even the company itself and respective brands, something that is becoming more frequent nowadays (Alturas and Almeida, 2015).

This process of transmitting information from person to person is called word-of-mouth (Richins and RootShaffer, 1988). In social networks, this transmission of information allows the organization to become more visible, 
project its notoriety, attract new partners or customers and increase its networking and social capital, all with low financial costs (Jansen, et al., 2009).

The broad scope of word-of-mouth in social networks gives organizations a geographic and timeless influence, and gives customers the opportunity to influence the image of the brands and perceptions of other customers. Therefore, organizations should be careful with the message they want to pass, when initiating word-of-mouth operations, because once the campaigns are launched, they become unmanageable because the tools do not provide the resources to manage the flow and information content (Jansen et al., 2009).

Few studies have been carried out considering the NGOs and their relationship with social networks (Waters and Lo, 2012). Waters, Burnett, Lamm and Lucas (2009) conducted a study to understand how these organizations use Facebook to publicize their missions and programs. The study found that there were three dimensions in the profiles of these organizations: information dissemination, organizational disclosure and involvement.

The information dissemination includes the following items on the pages: the existence of links to news, photographs, videos and audio, the presence of a discussion board, the publication of advertisements and links to press releases, and the publication of summaries of the campaigns. In the organizational disclosure, the presence of the items is considered: description of the organization's programs and services, history and mission, indication of the organization's website, logo and administrators of the profile. Finally, at the level of involvement, organizations are evaluated for the availability of means of contact (e-mail and telephone), message board and organizational calendar of events, presentation of volunteer opportunities and donations and a presence of an ecommerce store (Waters et al., 2009).

In fact, the information dissemination is major, as refer Martins, Santos and Batalha (2012) saying that organizations by allowing their team, volunteers and beneficiaries to tell their stories through videos, conveying positive emotions and obvious results, will inspire, motivate and act from donors and potential donors (Martins et al., 2012).

Also, the study carried out by Goecks, Voida, Voida and Mynatt (2008), conducted in the USA highlighted the role of technology in fundraising by revealing that the fundraising cycle involves three phases: (i) membership, (ii) donation, and (iii) feedback. The association phase can lead to donations and successful feedback can lead to stronger associations and additional donations, allowing the continuation of the cycle.

Finally, Waters and Lo (2012) conducted a study including NGOs from the United States of America, China and Turkey, to understand the impact of culture on the use of Facebook. The study recognized the rapid adoption of social networks by this type of organizations. However, it showed that these organizations do not enjoy all the options that the application offers, and that only 14\% of the 225 NGOs used the application to raise funds, including donations.

In this context, it is understood that Facebook is an important dissemination tool that can be better used by NGOs. Facebook can influence the reputation of an organization, and so the relationship between the reputation of businesses and social networks is essential, since it influences the behavior of consumers (Alturas and Oliveira, 2016), and if Facebook influence consumers in relation to a business, also influences donors towards an NGO, but for this it is necessary to know the real impacts that this tool has on donation practices.

\section{METHODOLOGY}

\section{Problem Definition}

In view of the defined objectives, a quantitative research strategy was used, that enable data collection on the facts and study the relationship between them (Bell, 2002). In fact, the organization under study is "Leigos para o Desenvolvimento" (People for Development), a non-profit association, recognized as NGDO, founded on April 11, 1986. Leigos para o Desenvolvimento have development projects in Angola, Mozambique, Portugal and S. Tomé and Príncipe, working in formal and informal training and education, community dynamization and organization, entrepreneurship and employability, training of local agents, promotion of volunteerism and pastoral work. Its work is done through young volunteers who remain on the ground for a minimum of one year.

The choice of this organization was due to be an organization that early thought of ways to ensure its financial sustainability and thus ensure that it continues to fulfill its mission. An example of this reality is the constitution of the Advisory Council for Sustainability, which aims to contribute to the elaboration of the Strategic Plan for Resource Mobilization. In addition, it is an organization that guarantees the contribution of various sources of funding to develop its activity, benefiting from the professionalization of the fundraising function, highlighting, in 2014, contributions from private benefactors (43\%), Merchandising ( $6 \%$ ), public financing (22\%), companies $(18 \%)$ and direct project revenue $(7 \%)$, which relate to the income generated by the projects themselves, such as enrolments, monthly sales, product sales and services (Leigos para o Desenvolvimento, 2015). 
Journal of Information Systems Engineering \& Management, 3(1), 04

Table 1. Descriptive statistics for Satisfaction with Facebook page items and word-of-mouth assessment

\begin{tabular}{|c|c|c|c|c|c|c|c|c|}
\hline Items & $\mathbf{N}$ & Mean & $\begin{array}{c}\text { Standard } \\
\text { Deviation }\end{array}$ & Min & Quartile 1 & Median & Quartile 3 & Max \\
\hline \multicolumn{9}{|l|}{ Satisfaction with Facebook ${ }^{(1)}$} \\
\hline $\begin{array}{l}\text { Description of the organization's programs and } \\
\text { services }\end{array}$ & 85 & 4.1 & 0.9 & 1.0 & 3.0 & 4.0 & 5.0 & 5.0 \\
\hline Organizational history & 77 & 3.7 & 0.9 & 1.0 & 3.0 & 4.0 & 4.0 & 5.0 \\
\hline Mission statement & 82 & 4.0 & 1.0 & 1.0 & 3.0 & 4.0 & 5.0 & 5.0 \\
\hline News Links & 82 & 4.0 & 0.9 & 2.0 & 3.0 & 4.0 & 5.0 & 5.0 \\
\hline Campaign Disclosure & 85 & 4.2 & 0.9 & 1.0 & 4.0 & 4.0 & 5.0 & 5.0 \\
\hline Photographs posted & 87 & 4.2 & 1.0 & 1.0 & 4.0 & 4.0 & 5.0 & 5.0 \\
\hline Videos posted & 73 & 3.8 & 1.2 & 1.0 & 3.0 & 4.0 & 5.0 & 5.0 \\
\hline Audio files posted & 68 & 3.5 & 1.1 & 1.0 & 3.0 & 4.0 & 4.0 & 5.0 \\
\hline Discussions & 61 & 3.5 & 1.1 & 1.0 & 3.0 & 3.0 & 4.0 & 5.0 \\
\hline Events Calendar & 76 & 3.9 & 1.1 & 1.0 & 3.0 & 4.0 & 5.0 & 5.0 \\
\hline Volunteer opportunities & 81 & 3.8 & 1.1 & 1.0 & 3.0 & 4.0 & 5.0 & 5.0 \\
\hline How to make donations & 82 & 3.9 & 1.1 & 1.0 & 3.0 & 4.0 & 5.0 & 5.0 \\
\hline Information about organization projects & 83 & 3.9 & 1.0 & 1.0 & 3.0 & 4.0 & 5.0 & 5.0 \\
\hline Testimonials of volunteers & 84 & 4.2 & 0.9 & 2.0 & 4.0 & 4.0 & 5.0 & 5.0 \\
\hline Cooperation/donation announcements & 76 & 3.9 & 1.1 & 1.0 & 3.0 & 4.0 & 5.0 & 5.0 \\
\hline Religious content & 74 & 3.6 & 1.1 & 1.0 & 3.0 & 4.0 & 4.0 & 5.0 \\
\hline Initiatives of other social organizations & 67 & 3.4 & 1.0 & 1.0 & 3.0 & 3.0 & 4.0 & 5.0 \\
\hline Overall satisfaction with the Facebook page (2) & 92 & 7.1 & 1.7 & 2.0 & 6.0 & 7.0 & 8.0 & 10.0 \\
\hline \multicolumn{9}{|l|}{ Word-of-mouth ${ }^{(3)}$} \\
\hline $\begin{array}{l}\text { I talk to people I know about Leigos para o } \\
\text { Desenvolvimento. }\end{array}$ & 195 & 5.4 & 1.9 & 1.0 & 4.0 & 6.0 & 7.0 & 7.0 \\
\hline $\begin{array}{l}\text { I mean in a positive way, Leigos para o } \\
\text { Desenvolvimento in the conversations I have with } \\
\text { friends and acquaintances. }\end{array}$ & 184 & 5.8 & 1.6 & 1.0 & 5.0 & 6.0 & 7.0 & 7.0 \\
\hline $\begin{array}{l}\text { In social contexts, I always speak favorably about } \\
\text { Leigos para o Desenvolvimento. }\end{array}$ & 180 & 5.9 & 1.5 & 1.0 & 5.0 & 6.0 & 7.0 & 7.0 \\
\hline
\end{tabular}

Notes: (1) scale 1 (very dissatisfied) to 5 (very satisfied)

(2) scale 1 (very dissatisfied) to 5 (very satisfied)

(3) scale 1 (strongly disagree) to 7 (strongly agree)

These results are due, in a certain way, to the fact that Leigos para o Desenvolvimento use different forms of communication with its stakeholders, such as the press, Facebook, the organization's website and newsletters. The Facebook page was created in March 2011, currently has more than 11,021 likes (reference March 2016), compared to only 1,220 at the end of 2011 (figures reported by the Leigos para o Desenvolvimento professional fundraiser). This strong growth in the number of likes is partially explained by the regular and varied posts that reinforce the universe and the culture of the organization. It is these connoisseurs of Leigos para o Desenvolvimento and, particularly, of their Facebook page that constitute the target population of this study.

\section{Data Collection}

Since the target population is geographically dispersed, it was decided to collect the data through questionnaires sent by e-mail to a group of individuals that are registered in the databases of the organization. In addition, the questionnaire was also posted on the organization's Facebook page, and individual and personalized invitations were made to Facebook users by sending private messages. The data collection process was performed between August 4 and 24, 2015. In total, 204 completed questionnaires were validated.

The questionnaire had two pre-tests, the first one with people with different levels of involvement with the organization (people with no connection to the organization, volunteers, friends of the organization, employees) and the second with people who did not know the organization. These pre-tests resulted only in changes to the text of some questions and to their order. The questions included in the questionnaire, adapted from the literature, were validated by the Leigos para o Desenvolvimento professional fundraiser and by an academic, marketing and fundraising specialist. These professionals also followed the whole study, contributing to the interpretation of the results.

For the analysis of satisfaction with the Facebook page, 17 items on the page were used, taken from the list presented by Waters, Burnett, Lamm and Lucas (2009, p. 104), having resorted to a scale of five points, from 1 (very dissatisfied) to 5 (very satisfied). In addition, a question was included to evaluate satisfaction with the Facebook page, considering a scale from 1 (totally dissatisfied) to 10 (totally satisfied). To measure the word-ofmouth on the organization, a seven-point concordance scale was used, from 1 (totally disagree) to 7 (totally agree), for the evaluation of agreement with three statements adapted from Harrison-Walker (2001). This set of items is presented in Table 1 and reflects, not only word-of-mouth in social networks, but also personally, in contacts with family, friends and acquaintances.

Lastly, in terms of donation practices, participants were asked about their past behavior, and particularly, if donations were made in the last year to Leigos para o Desenvolvimento, the frequency with which they donate 
Table 2. PCA results for satisfaction with the Facebook page

\begin{tabular}{|c|c|c|c|c|}
\hline \multirow[b]{2}{*}{ Facebook characteristics } & \multirow[b]{2}{*}{ Communality } & \multicolumn{3}{|c|}{ Components and Loadings } \\
\hline & & $\begin{array}{l}\text { Organizational } \\
\text { disclosure }\end{array}$ & $\begin{array}{c}\text { Information } \\
\text { dissemination }\end{array}$ & Involvement \\
\hline Description of the organization's programs and services & 0.868 & 0.876 & & \\
\hline Organizational history & 0.854 & 0.874 & & \\
\hline Mission statement & 0.899 & 0.894 & & \\
\hline Photographs posted & 0.822 & & 0.827 & \\
\hline Videos posted & 0.930 & & 0.894 & \\
\hline Audio files posted & 0.864 & & 0.810 & \\
\hline Volunteer opportunities & 0.685 & & & 0.597 \\
\hline How to make donations & 0.584 & & & 0.599 \\
\hline Testimonials of volunteers & 0.800 & & & 0.871 \\
\hline Cooperation/donation announcements & 0.860 & & & 0.842 \\
\hline Initial variance explained after rotation $(\%)$ & & $28.89 \%$ & $27.22 \%$ & $25.55 \%$ \\
\hline Eigenvalues & & 5.879 & 1.367 & 0.919 \\
\hline Cronbach's Alpha & & 0.922 & 0.915 & 0.852 \\
\hline
\end{tabular}

Results after Equamax rotation

$\mathrm{KMO}=0.822 ; \operatorname{Bartelett}_{(45)}=536.441 ; \mathrm{p}<0.001 ; \mathrm{n}=65$

Table 3. Results of composite reliability and convergent and discriminant validity of satisfaction components with Facebook page

\begin{tabular}{l|cccc|ccc}
\hline & CR & AVE & MSV & ASV & $\begin{array}{c}\text { Information } \\
\text { dissemination }\end{array}$ & $\begin{array}{c}\text { Oganizational } \\
\text { disclosure }\end{array}$ & Involvement \\
\hline Information dissemination & 0.822 & 0.713 & 0.462 & 0.390 & 0.844 & & \\
\hline Organizational disclosure & 0.913 & 0.777 & 0.328 & 0.323 & 0.563 & 0.881 & \\
\hline Involvement & 0.823 & 0.546 & 0.462 & 0.395 & 0.680 & 0.573 & 0.739 \\
\hline Not
\end{tabular}

Note: Satisfactory indications by Fornell and Larker (1981) and Garver and Mentzer (1999): CR > 0.7; AVE > 0.5; CR > AVE; MSV < AVE; ASV < AVE

and the amount donated in the last 12 months. These were also asked about the intention to donate in the future. These donations practices are those usually studied (Srnka et al., 2003; Abreu et al., 2015).

\section{Data Analysis Techniques}

Data analysis was based on statistical techniques of univariate and bivariate analysis and linear regression models, using the IBM SPSS Statistics software (version 23). To identify significant differences in the levels of satisfaction with Facebook, the Mann-Whitney and Kruskal-Wallis tests were used for independent samples, considering a significance level of 0.1 (only for this level are significant differences in distributions). It should be noted that the violation of the assumption related to the normal distribution prevented the performance of the parametric tests $\mathrm{t}$ and $\mathrm{F}$ (one-way ANOVA). In addition, it was considered that there is a relationship between satisfaction with Facebook and donation practices whenever the measure of association (Spearman or Eta) has a coefficient, in absolute terms, higher than 0.2.

Initially, a Principal Components Analysis (PCA) was carried out to identify dimensions of satisfaction with the Facebook page. The solution adopted revealed the suitability of the data $(\mathrm{KMO}=0.822$; Bartelett $(45)=536.441$; $\mathrm{p}<0.001$ ) and the retention of three components that explain $81.7 \%$ of the total variance (Table 2 ). It is noteworthy that this solution was obtained after the exclusion of several items because they had communality less than 0.5 or loadings greater than 0.5 in two components, making it difficult to interpret the satisfaction components (Hair et al., 2010). The components were designated by organizational disclosure, Information Dissemination and Involvement, as Waters et al. (2009) suggested, and presented an adequate Cronbach's Alpha greater than 0.7 (Hair et al., 2010).

The components underwent a validation regarding Composite Reliability, Convergent Validity and Discriminant. Composite Reliability ( $\mathrm{CR}>0.7)$ captures the degree to which the items behave in a similar manner, relating to a common latent construct (Bagozzi and Yi, 1988). Convergence Validity was evaluated through the average variance extracted measure (AVE $>0.5$ ) and Discriminant validity is verified when the square root of AVE for each construct is greater than the standardized correlation of that construct with all other constructs (Fornell and Larcker, 1981), can be measure by Maximum Shared Squared Variance (MSV) and Average Shared Square Variance (ASV). The values obtained for the composite reliability, convergent and discriminant validities, and Factor Correlation Matrix with square root of the AVE, are presented at Table 3.

We also evaluated the internal consistency of word-of-mouth that was found to be strong (Cronbach's Alpha of 0.913 , all correlations between the statements and the global scale were greater than 0.7 , and the exclusion of any statement of the construct would make the value of Cronbach's Alpha decrease). 
Journal of Information Systems Engineering \& Management, 3(1), 04

Table 4. Satisfaction with the Facebook page

\begin{tabular}{|c|c|c|c|c|c|c|c|c|}
\hline Dimensions of satisfaction with Facebook & $\mathbf{N}$ & Mean & $\begin{array}{l}\text { Standard } \\
\text { Deviation }\end{array}$ & Min & Quartile 1 & Median & Quartile 3 & Max \\
\hline \multicolumn{9}{|l|}{ Satisfaction with Facebook (1) } \\
\hline Organizational disclosure & 77 & 3.9 & 0.9 & 1.0 & 3.3 & 4.0 & 4.7 & 5.0 \\
\hline Information dissemination & 68 & 3.8 & 1.0 & 1.0 & 3.2 & 4.0 & 4.7 & 5.0 \\
\hline Involvement & 75 & 3.9 & 0.9 & 1.3 & 3.3 & 4.0 & 4.8 & 5.0 \\
\hline Overall satisfaction with Facebook page (2) & 92 & 7.1 & 1.7 & 2.0 & 6.0 & 7.0 & 8.0 & 10.0 \\
\hline
\end{tabular}

Notes: (1) scale 1 (very dissatisfied) to 5 (very satisfied)

(2) scale 1 (totally dissatisfied) to 10 (totally satisfied)

Table 5. Propensity for word-of-mouth formation

\begin{tabular}{lccccccc}
\hline Word-of-mouth formation & N & Mean & $\begin{array}{c}\text { Standard } \\
\text { Deviation }\end{array}$ & Min & Quartile 1 & Median Quartile 3 & Max \\
\hline Word-of-mouth (1) & 178 & 5.8 & 1.5 & 1.0 & 5.0 & 6.0 & 7.0 \\
\hline Nord
\end{tabular}

Note: (1) scale 1 (low intensity) to 7 (high intensity)

The components of satisfaction with Facebook were operationalized through composite indexes, which correspond to the average of responses to the items most correlated with the component, being measured on a continuous scale from 1 (very dissatisfied) to 5 (very satisfied). Word-of-mouth was also implemented by averaging the responses to the three statements (index) that constitute it, being measured on a scale from 1 (very low) to 7 (very high).

To evaluate the contribution of the components of satisfaction with Facebook in the development of the wordof-mouth, multiple linear regression models were used, using the Enter method to introduce the explanatory variables in the model. When non-significant variables were identified, another model with only the significant variables was estimated.

\section{RESULTS}

\section{Sample Characterization}

Respondents with Leigos para o Desenvolvimento knowledge are female (65.7\%) aged 20-79 years, with a mean of 39.7 years. Relatively to the family situation, it is verified that they are essentially married $(49.6 \%)$ or single $(43.5 \%)$ and $30.8 \%$ have a household with two elements. They live in large numbers in the municipality of Lisbon (41.1\%), where the organization has its headquarters. Most of the respondents $(91.2 \%)$ have higher education qualifications and tend to bedependent workers $(65.3 \%)$, with a monthly gross income of household very diverse.

\section{Satisfaction with the organization's Facebook page}

As mentioned, satisfaction with the organization's Facebook page is evaluated in three dimensions and in its entirety. In this evaluation, less than half of the individuals responded to all satisfaction items (and only 65 evaluated Facebook in the three satisfaction components) and that there is no clear tendency for full satisfaction with Facebook (Table 1 and Table 4). In fact, the mean values of satisfaction with the three components present values close to 4 and, when evaluated in the global, the average satisfaction is of 7.1. There is still a low dispersion of evaluations, but there are some individuals who are very dissatisfied and others who are very satisfied.

\section{Word-of-mouth and Donation Practices}

The propensity for individuals to practice word-of-mouth about the organization is assessed by agreement with three statements which were classified in a Likert scale with seven points, varying from 1 (strongly disagree) to 7 (strongly agree). The results show that the mean level of agreement with the statements ranges from 5.4, to "I speak about Leigos para o Desenvolvimento with people I know," to 5.9, for "In social contexts, I always speak favorably about Leigos para o Desenvolvimento" (Table 1). These values show a high intensity in the formation of the word-of-mouth about Leigos para o Desenvolvimento, either in an online environment or not, resulting in an overall mean of 5.8, with low dispersion (Table 5).

Regarding donation practices, Leigos para o Desenvolvimento connoisseurs were asked about their intention to make monetary donations in the future. The results (Table 6) show that the majority $(72.1 \%)$ intend to make a monetary donation. Beyond the expectation of future behaviour, individuals were also asked about their past and current behaviours. Most respondents (57.4\%) did not donate to Leigos para o Desenvolvimento in the last year, but those who did (87 donors) say they do it once a year (55.2\%), two or three times a year $(26.4 \%)$, more than three times a year $(5.7 \%)$ and every month (12.6\%). In addition, it is verified that 63 donors of the Leigos para o Desenvolvimento affirm they made donations in the last year, with a minimum of 5 euro and a maximum of 5,000 
Table 6. Descriptive statistics for Donation practices

\begin{tabular}{|c|c|c|}
\hline Donation practices & $\mathbf{N}$ & $\%$ \\
\hline \multicolumn{3}{|c|}{ Donations in the last 12 months } \\
\hline No & 117 & 57.4 \\
\hline Yes & 87 & 42.6 \\
\hline Total & 204 & 100.0 \\
\hline \multicolumn{3}{|l|}{ Frequency of donations } \\
\hline Once a year & 48 & 55.3 \\
\hline 2 or 3 times a year & 23 & 26.4 \\
\hline More than 3 times a year & 5 & 5.7 \\
\hline Every month & 11 & 12.6 \\
\hline Total & 87 & 100.0 \\
\hline \multicolumn{3}{|c|}{ Amount donated in the last 12 months } \\
\hline 5 to 20 Euros & 14 & 22.2 \\
\hline 21 to 50 Euros & 19 & 30.2 \\
\hline 51 to 100 Euros & 18 & 28.6 \\
\hline More than 100 Euros & 12 & 19.0 \\
\hline Total & 63 & 100.0 \\
\hline \multicolumn{3}{|c|}{ Intention to make donations in the future } \\
\hline No & 57 & 27.9 \\
\hline Yes & 147 & 72.1 \\
\hline Total & 204 & 100.0 \\
\hline
\end{tabular}

Table 7. Results of the linear regression model for the word-of-mouth explanation

\begin{tabular}{|c|c|c|c|c|c|c|}
\hline Model & Independent variables & Coefficients & $\begin{array}{c}\text { Standard } \\
\text { error }\end{array}$ & $\begin{array}{c}\text { Standard } \\
\text { coefficients }\end{array}$ & $t$ test & Model quality \\
\hline \multirow{4}{*}{$\begin{array}{c}1.1 \\
(\mathrm{n}=60)\end{array}$} & Constant & 4.035 & 0.788 & & $5.122^{* * *}$ & \multirow{4}{*}{$\begin{array}{l}\mathrm{F}(3 ; 56)=3.014^{*} \text { adjusted } \mathrm{R}^{2}=9.3 \% \\
\text { Standard error of estimate }=1.223\end{array}$} \\
\hline & Organizational disclosure & 0.200 & 0.218 & 0.145 & 0.918 ns & \\
\hline & Information dissemination & 0.389 & 0.218 & 0.316 & $1.787^{+}$ & \\
\hline & Involvement & -0.090 & 0.255 & -0.063 & $-0.355 \mathrm{~ns}$ & \\
\hline \multirow{2}{*}{$\begin{array}{c}1.2 \\
(\mathrm{n}=62)\end{array}$} & Constant & 4.254 & 0.579 & & $7.345^{* * * *}$ & \multirow{2}{*}{$\begin{array}{l}\mathrm{F}(1 ; 60)=9.512^{* *} \text { adjusted } \mathrm{R}^{2}=12.2 \% \\
\text { Standard error of estimate }=1.193\end{array}$} \\
\hline & Information dissemination & 0.449 & 0.146 & 0.370 & $3.084^{* *}$ & \\
\hline \multirow{2}{*}{$\begin{array}{c}2 \\
(\mathrm{n}=83)\end{array}$} & Constant & 3.926 & 0.498 & & $7.880^{* * *}$ & \multirow{2}{*}{$\begin{array}{l}\mathrm{F}(1 ; 81)=19.480^{* * *} \text { asjusted } \mathrm{R}^{2}=18.4 \% \\
\text { Standard error of estimate }=1.092\end{array}$} \\
\hline & Overall satisfaction & 0.301 & 0.068 & 0.440 & $4.414^{* * *}$ & \\
\hline
\end{tabular}

euro. However, the donations mean was 199 euro, with extremely high dispersion (657 euro). Thus, the median analysis shows that half of these donors donated a maximum of 50 euro.

\section{Effect of Facebook Satisfaction on Word-of-mouth and Donation Practices}

Satisfaction with Facebook, both in its components and in the overall satisfaction, reveals a positive effect on word-of-mouth formation. In fact, the results of the estimated multiple linear regression models (Table 7) show that satisfaction with information dissemination significantly explains word-of-mouth (model $1.2-B=0.499 ; t=$ 3.084; $p=0.003$ ). However, when satisfaction with dissemination form varies itself by 1 point (from 1 to 5 ), wordof-mouth vary itself, on mean, and in the same sense, by 0.449 points (scale from 1 to 7 ). Thus, the greater the satisfaction with the form of information dissemination, the greater the tendency of a word-of-mouth creation, contributing to the explanation of $12.2 \%$ of the variance of the word-of-mouth.

Although the components of satisfaction, organizational disclosure and involvement, are not significant, when analysed singly, these are reflected in the overall satisfaction with Facebook, which evidences a significant positive relation with word-of-mouth creation (model $2-B=0.301, t=4.414, p<0.001$ ). Overall satisfaction explains $18.4 \%$ of the variance of the word-of-mouth, showing that when overall satisfaction varies itself by 1 point (scale from 1 to 10), the word-of-mouth vary itself, on mean, and in the same sense, by 0.301 points (scale from 1 to 7 ).

Regarding the influence of Facebook page satisfaction on donation practices, it is significant in relation to the frequency with which donations are made and their amounts. Thus, satisfaction has no impact on the act of giving, nor on the intention of accomplishing it, that is, the satisfaction mean values are similar between those who gave and did not give or between who intends to do and do not do (Table 8). 
Journal of Information Systems Engineering \& Management, 3(1), 04

Table 8. Relationship between Facebook satisfaction and donation practices

\begin{tabular}{|c|c|c|c|c|c|c|c|c|c|c|c|c|c|}
\hline \multirow[t]{2}{*}{ Donation practices } & \multicolumn{3}{|c|}{$\begin{array}{l}\text { Organizational } \\
\text { disclosure }\end{array}$} & \multicolumn{3}{|c|}{$\begin{array}{c}\text { Information } \\
\text { dissemination }\end{array}$} & \multicolumn{3}{|c|}{ Involvement } & \multicolumn{3}{|c|}{ Overall Satisfaction } & \multirow[t]{2}{*}{ Result (1) } \\
\hline & $\mathbf{N}$ & Mean & St dev & $\mathbf{N}$ & Mean & St dev & $\mathbf{N}$ & Mean & St dev & $\mathbf{N}$ & Mean & St dev & \\
\hline \multicolumn{13}{|c|}{ Donations in the last 12 months } & \multirow{4}{*}{ - There is no relationship } \\
\hline No & 38 & 4.0 & 0.8 & 34 & 3.8 & 0.9 & 38 & 3.9 & 0.9 & 43 & 7.0 & 1.7 & \\
\hline \multirow[t]{2}{*}{ Yes } & 39 & 3.8 & 1.0 & 3.4 & 3.9 & 1.1 & 37 & 4.0 & 0.9 & 49 & 7.1 & 1.8 & \\
\hline & \multicolumn{3}{|c|}{$M W=683.5 ; p=0.557$} & \multicolumn{3}{|c|}{$M W=522.0 ; p=0.492$} & \multicolumn{6}{|c|}{$M W=631.5 ; p=0.449 M W=1011.5 ; p=0.740$} & \\
\hline \multicolumn{13}{|l|}{ Frequency of donations } & \multirow{6}{*}{$\begin{array}{l}\text { There is some relationship } \\
\text { Involvement: } \text { Rho }=-0.249\end{array}$} \\
\hline Once a year & 19 & 3.9 & 1.0 & 15 & 3.9 & 1.4 & 17 & 4.1 & 0.9 & 25 & 7.0 & 1.9 & \\
\hline 2 or 3 times a year & 13 & 3.9 & 1.0 & 12 & 4.1 & 0.9 & 13 & 4.2 & 0.8 & 15 & 7.5 & 1.7 & \\
\hline More than 3 times a year & 3 & 4.2 & 1.1 & 3 & 4.2 & 0.8 & 3 & 4.0 & 0.5 & 3 & 7.7 & 1.2 & \\
\hline Every month & 4 & 2.8 & 0.3 & 4 & 3.1 & 0.2 & 4 & 3.1 & 0.1 & 6 & 6.0 & 2.0 & \\
\hline Test of Kruskal-W & \multicolumn{3}{|c|}{$K W=5.726 ; p=0.121$} & \multicolumn{3}{|c|}{$K W=4.292 ; p=0.238$} & \multicolumn{3}{|c|}{$K W=6.581 ; p=0.078$} & \multicolumn{3}{|c|}{$K W=4.306 ; p=0.235$} & \\
\hline \multicolumn{13}{|c|}{ Amount donated in the last 12 months } & \multirow{6}{*}{$\begin{array}{l}\text { - There is a relationship } \\
\text { - Disclosure: } \text { Rho }=-0.218 \\
\text { - Dissemination: } \text { Rho }=-0.491 \\
\text { - Involvement: } R h o=-0.459 \\
\text { - Overall Sat: } \text { Rho }=-0.412\end{array}$} \\
\hline 5 to 20 Euro & 5 & 3.9 & 1.0 & 2 & 4.0 & 1.4 & 4 & 4.1 & 0.9 & 7 & 7.3 & 0.9 & \\
\hline 21 to 50 Euro & 8 & 3.9 & 1.0 & 9 & 4.4 & 0.6 & 8 & 4.6 & 0.5 & 10 & 7.9 & 1.3 & \\
\hline 51 to 100 Euro & 7 & 3.7 & 1.4 & 7 & 3.4 & 1.4 & 7 & 3.4 & 1.0 & 11 & 6.5 & 1.6 & \\
\hline More than 100 Euro & 5 & 3.3 & 0.8 & 4 & 3.1 & 0.3 & 4 & 3.3 & 0.9 & 5 & 5.2 & 1.8 & \\
\hline Test of Kruskal-W & \multicolumn{3}{|c|}{$K W=1.858 ; p=0.623$} & \multicolumn{3}{|c|}{$K W=6.191 ; p=0.088$} & \multicolumn{3}{|c|}{$K W=7.758 ; p=0.040$} & \multicolumn{3}{|c|}{$K W=8.487 ; p=0.030$} & \\
\hline \multicolumn{13}{|c|}{ Intention to make donations in the future } & \multirow{4}{*}{ There is no relation } \\
\hline$\overline{\mathrm{No}}$ & 1.9 & 3.8 & 0.8 & 17 & 3.8 & 1.1 & 18 & 3.9 & 1.0 & 21 & 6.7 & 1.7 & \\
\hline Yes & 58 & 3.9 & 0.9 & 51 & 3.8 & 1.0 & 57 & 4.0 & 0.8 & 71 & 7.2 & 1.8 & \\
\hline \multicolumn{4}{|c|}{ Test of Mann-Whitney $M W=472.5 ; p=0.353$} & \multicolumn{3}{|c|}{$M W=430.5 ; p=0.969$} & \multicolumn{3}{|c|}{$M W=491.0 ; p=0.788$} & \multicolumn{3}{|c|}{$M W=602.0 ; p=0.176$} & \\
\hline
\end{tabular}

Note: (1) Only those association measures with a higher value, in magnitude, to 0.2 were presented.

We also assessed satisfaction with Facebook page regarding the donation frequencies (Table 8). It leads to the conclusion, on the one hand, that it is not on Facebook that monthly donors find motivation (lower satisfaction means in all components). On the other hand, there is a slight tendency to increase the frequency of donation as satisfaction of information about involvement decreases (who gives once a year has a satisfaction mean of 4.1 and who gives every month has a mean of $3.1-$ Spearman Rho $=-0.249$ ).

None the less, the relationship between satisfaction with Facebook page and the donated value in the last year is more noticeable, and the lower the satisfaction, whatever its component, the higher the value of the donations tends to be. For example, the overall mean satisfaction of those who give low amounts (mean of 5 to 20 euro $=$ 7.3) is much higher than those that give high amounts (mean of more than 100 euro $=5.2$ ).

\section{CONCLUSIONS AND IMPLICATIONS}

This study intends to evaluate, for an NGDO, the relevance of its profile in Facebook to the recognition and recognition of the merit of the organization (as measured by its spread through the word-of-mouth) and to fundraising.

The organization studied is on the right path. Satisfaction with the Facebook page is good, in its three aspects and overall, so it can be concluded that it contributes to the establishment of a relationship of trust and openness with stakeholders. Additionally, satisfaction with the dissemination of information reveals that the Facebook page component can influence the formation of the word-of-mouth, which in this organization is high, showing the indispensability of organizations to contemplate in their profiles photography, video and audio, to better illustrate their causes and the fulfillment of their missions. In addition, more static content and messages are important, concluding that overall satisfaction with the page also has a positive impact on word-of-mouth training.

However, at the level of fundraising, satisfaction with Facebook page, itself, is not decisive for making donations, either in the present or as a future intention. But for those who donate, it has an impact on the frequency of donations and, essentially, on donations value. Indeed, frequency tends to decrease slightly with increased satisfaction associated with involvement information, which includes disclosure of testimony, opportunities for volunteers, and donations for certain causes, leading to the conclusion that this type of Information may cause a donation, but not its repetition. It is also concluded that for monthly donors, whose satisfaction is lower than that of less frequent donors, it is not the information published on Facebook that leads to this monthly regularity, but rather the type of relationship that these donors may have with the organization (volunteer, elder, trainer, among others). In terms of value, it is not because donors are more satisfied that they will contribute to organizations with higher amounts, nevertheless greater satisfaction may lead to the realization of a donation, even if it is of low value.

These results at the level of donation practices reveal that organizations still must better exploit social networks to increase the donations raised. For example, they can incorporate on the page the possibility of online donations, which in a way can encourage the youngest and most adventurous donors of Facebook and causes, to make donations and more frequent. 
It is concluded, therefore, that Facebook is a valuable means for NGOs to contribute to the financial sustainability of these organizations by fostering not only fundraising and donors, but also a closer relationship with NGOs. The current donors, which can translate into an increase in the rate of donor retention, which tends to be low in this type of organization.

Although the study focuses only on one organization and includes a sample that may not represent all the population extracts, it reveals a valid contribution to the knowledge about NGOs in Portugal and, particularly, about the fundraising activity. It shows to the professionals of these organizations the need for an alignment between the fundraising and communication strategy and the ICT strategy. This alignment requires additional studies and a broadening of scope to other technologies and platforms, including mobile.

\section{REFERENCES}

Abreu, M., Laureano, R., Silva, R. and Dionísio, P. (2015). Volunteerism, compassion and religiosity as drivers of donations practices. International Journal of Nomprofit and Voluntary Sector Marketing, 20(3), 256-276. https://doi.org/10.1002/nvsm.1526

Alturas, B. and Almeida, C. (2015). Social networks as a platform for business marketing. LCBR European Marketing Conference 2015. Lisbon, Portugal.

Alturas, B. and Oliveira, L. S. (2016). Consumers using Social Media: Impact on Companies' Reputation. Radical Marketing, Academy of Marketing Annual Conference Proceedings, Newcastle Business School at Northumbria University, UK, pp. 156.

Andrade, A. and Franco, R. (2007). Economia do conbecimento e organizações sem fins lucrativos (Knowledge economy and nonprofit organizations). Porto, Portugal: Sociedade Portuguesa de Inovação.

Azevedo, C. and Couto, P. (2012). Desempenho, Sustentabilidade e Eficiência Económica em OSFL - Como fazer de Sísifo um Mito? in C. Azevedo, R. Franco and J. Meneses (eds.), Gestão de Organizações sem Fins Lucrativos - O Desafio da Inovação Social (pp. 371-407), Porto, Portugal: Impulso Positivo.

Bagozzi, R. P. and Yi, Y. (1988). On the Evaluation of Structural Equation Models. Journal of the Academy of Marketing Science, 16(1), 74-94.

Barreto, A. M. (2013). Do Users Look at Banner Ads on Facebook?. Journal of Research in Interactive Marketing, 7(2), 119-139.

Bell, J. (2002). Doing Your Research Project: A Guide for First-Time Researchers. Open University Press.

Belo, A., Castela, G. and Fernandes, S. (2013). Collaborative Virtual Environments: potential of social networks. The case of companies in the Algarve. Revista Ibérica de Sistemas e Tecnologias de Informação, (12), 65-79. https://doi.org/10.4304/risti.12.65-79

CASES (2016). Conta Satélite da Economia Social (Social Economy Satellite Account). Lisboa, Portugal: Instituto Nacional de Estatística e Cooperativa António Sérgio para a Economia Social.

Cheung, C., Lee, M. and Rabjohn, N. (2008). The impact of electronic word of mouth: The adoption of online opinions in online customer communities. Internet Research, 18(3), 229-247. https://doi.org/10.1108/10662240810883290

Cheung, C. and Thadani, D. (2012). The impact of electronic word-of-mouth communication: a literature analysis and integrative model. Decision Support Systems, 54(1), 461-470. https://doi.org/10.1016/j.dss.2012.06.008

Cho, M., Schweickart, T and Haase, A. (2014). Public engagement with nonprofit organizations on Facebook. Public Relations Review, 40(3), 565-567. https://doi.org/10.1016/j.pubrev.2014.01.008

Couttenier, M., and Hatte, S. (2016). Mass media effects on non-governmental organizations. Journal of Development Economics, 123, 57-72. https://doi.org/10.1016/j.jdeveco.2016.07.001

Ellison, N., Steinfeld, C. and Lampe, C. (2007). The Benefits of Facebook "Friends:" Social Capital and College Students' Use of Online Social Network Sites. Journal of Computer-Mediated Communication, 12(4), 1143-1168. https://doi.org/10.1111/j.1083-6101.2007.00367.x

Fornell, C., and Larcker, D. F. (1981). Evaluating Structural Equation Models with Unobservable Variables and Measurement Error. Journal of Marketing Research, 18(1), 39-50.

Goecks, J., Voida, A., Voida, S. and Mynatt, E. (2008). Charitable Technologies: Opportunities for Collaborative Computing in Nonprofit Fundraising. Proceedings of ACM CSCW08 Conference on Computer-Supported Cooperative Work, pp. 689-698. https://doi.org/10.1145/1460563.1460669

Guo, C. and Saxton, G. D. (2014). Tweeting Social Change: How Social Media Are Changing Nonprofit Advocacy. Nonprofit and Voluntary Sector Quarterly, 43(1), 57-79. https://doi.org/10.1177/0899764012471585

Hair, J., Black, W., Babin, J. and Anderson, R. (2010). Multivariate Data Analysis, 7th ed. Upper Saddle River: Pearson Education. 
Harrison-Walker, L. (2001). The measurement of word-of-mouth communication and an investigation of service quality and customer commitment as potential antecedents. Journal of Service Research, 4(1), 60-75. https://doi.org/10.1177/109467050141006

Higie, R., Feick, L and Price, L. (1987). Types and amount of word-of-mouth communications about retailers. Journal of Retailing, 63(3), 260-278.

Hollow, M. (2013). Crowdfunding and Civic Society in Europe: A Profitable Partnership?. Open Citizenship, 4(1), 68-73.

Hoogesteger, J. (2016). NGOs and the Democratization of Ecuadorian Water Governance: Insights from the Multi-Stakeholder Platform el Foro de los Recursos Hídricos. VOLUNTAS: International Journal of Voluntary and Nonprofit Organizations, 27(1), 166-186. https://doi.org/10.1007/s11266- 015-9559-1

Jansen, B., Zhang, M., Sobel, K. and Chowdury, A. (2009). Twitter power: Tweets as electronic word of mouth. Journal of the American Society for Information Science and Technology, 60(11), 2169-2188. https://doi.org/10.1002/asi.21149

Jesus, M., Laureano, R. and Fernandes, D. (2013). Evaluation of websites from an Accountability Perspective: Applying to the Portuguese Sports Federation. Working Paper-13/04, Instituto Universitário de Lisboa (ISCTE-IUL), Lisboa.

Kane, G., Alavi, M., Labianca, G. and Borgatti, S. (2014). What's different about social media networks? A framework and research agenda. MIS Quarterly, 38(1), 275-304.

Kaplan, R. (2001). Strategic Performance Measurement and Management in Nonprofit Organizations. Nonprofit Management and Leadership, 11(3), 353-370. https:// doi.org/10.1002/nml.11308

Leigos para o Desenvolvimento (2015). Relatório de Gestão e Contas 2014 (Management Report and Accounts 2014). Available at: http://www.leigos.org

LINI (2010). A utilização da internet em Portugal 2010 (The use of the Internet in Portugal 2010). Lisboa: LINI - Lisbon Internet and Networks International Research Programme.

Marktest (2014). Os Portugueses e as Redes Sociais 2014 (The Portuguese and Social Networks 2014). Lisboa: Grupo Marktest.

Martins, J., Gonçalves, R., Santos, V., Cota, M., Oliveira, T. and Branco, F. (2015). A Proposal for a Social eLearning Model2. Revista Ibérica de Sistemas e Tecnologias de Informação, (16), 92-107, https:/ / doi.org/10.17013/risti.16.92-107

Martins, R., Santos, N. and Batalha, S. (2012). Comunicação nas OSFL, in C. Azevedo, R. Franco, and J. Meneses (eds.), Gestão de Organizações sem Fins Lucrativos - O Desafio da Inovação Social (pp. 269-305). Porto, Portugal: Impulso Positivo.

Mazman, S. G. and Usluel, Y. K. (2010). Modeling educational usage of Facebook. Computers and Education, 55(2), 444-453. https:// doi.org/10.1016/j.compedu.2010.02.008

Modi, P. (2012). Market Orientation in Nonprofit Organizations: Innovativeness, Resource Scarcity, and Performance. Journal of Strategic Marketing, 20(1), 55-67. https://doi.org/10.1080/0965254X.2011.628405

Moro, S., Rita, P. and Vala, B. (2016). Predicting social media performance metrics and evaluation of the impact on brand building: A data mining approach. Journal of Business Research, 69(9), 3341-3351. https://doi.org/10.1016/j.jbusres.2016.02.010

Pinho, J. C. (2013). The e-SOCAPIT scale: a multi-item instrument for measuring online social capital. Journal of Research in Interactive Marketing, 7(3), 216-235.

Pritchard, M., Havitz, M. and Howard, D. (1999). Analyzing the Commitment-Loyalty Link in Services Contexts. Journal of the Academy of Marketing Science, 27(3), 333-348. https://doi.org/10.1177/0092070399273004

Rebelo, M., and Alturas, B. (2011). Social Networking as a Marketing Tool: Study of Participation in Cultural Events Promoted by Facebook. Marketing Fields Forever, Academy of Marketing Annual Conference Proceedings, Liverpool, UK, pp. 240.

Richins, M. and Root-Shaffer, T. (1988). The role of involvement and opinion leadership in consumer word-ofmouth: an implicit model made explicit. Advances in Consumer Research, 15(1), 32-36.

Salamon, L., Sokolowski, S., Haddock, M. and Tice, H. (2012). Portugal's Nonprofit Sector in Comparative Context. Johns Hopkins Center for Civil Society Studies and Instituto Nacional de Estatistica (INE).

Srnka, K, Grohs, R. and Eckler, I. (2003). Increasing Fundraising Efficiency by Segmenting Donors. Australasian Marketing Journal, 11(1), 70-86. https:// doi.org/10.1016/S1441-3582(03)70119-0

Subramani, M. and Rajagopalan, B. (2003). Knowledge-sharing and influence in online social networks via viral marketing. Communications of the ACM, 46(12), 300-307. https://doi.org/10.1145/953460.953514

Waters, R. and Lo, K. (2012). Exploring the Impact of Culture in the Social Media Sphere: A Content Analysis of Nonprofit Organizations Use of Facebook. Journal of Intercultural Communication Research, 41(3), 297-319. https://doi.org/10.1080/17475759.2012.728772 
Waters, R., Burnett, E., Lamm, A., and Lucas, J. (2009). Engaging stakeholders through social networking: How nonprofit organizations are using Facebook. Public Relations Review, 35(2), $102-106$. https://doi.org/10.1016/j.pubrev.2009.01.006

Wheat, R., Wang, Y., Byrnes, J. and Ranganathan, J. (2013). Raising money for scientific research through crowdfunding. Trends in Ecology and Evolution, 28(2), 71-72. https:/ / doi.org/10.1016/j.tree.2012.11.001

Young, J. A. (2017). Facebook, Twitter, and Blogs: "The Adoption and Utilization of Social Media in Nonprofit Human Service Organizations". Human Service Organizations: Management, Leadership \& Governance, 41(1), $44-57$. https://doi.org/10.1080/23303131.2016.1192574 